\title{
SHANGHAI: A (SELF)PORTRAIT
}

\author{
Maria Francesca PIAZZONI, Matteo BASSO
}

This special issue of the Journal of Architecture and Urbanism is the result of a conference that was organized at IUAV University of Venice in May 2015, where a series of conferences named City-Portraits has been hosted beginning in 2011. Each conference examines one city of the world with an inter-disciplinary perspective. We chose to focus on Shanghai, since we are both separately engaged in research on the city (Basso 2016; Piazzoni forthcoming). Interested in the representational regimes of Shanghai that emerge from within the city, we deviated from the norm of IUAV and named the conference Shanghai, a (Self)Portrait. Through this re-naming, we specifically aimed to shed light on the various analytical mediums and methods through which Shanghai is represented by its own actors. Structures of power and narratives of marginalization are powerfully brought to the fore through self-reflections. As a growing metropolis perpetually repositioning itself in the global arena, Shanghai offers a particularly rich case to investigate such dynamics.

Portraiture has long been understood as a social and cultural practice laden with political implications. Occupying a "default position as the art form of capitalist societies" (Pointon 2013: 9), portraiture complicates subject-object relations and aims to produce some form of truth (Foucault [1966] 2012). Selfportraiture emerged in the mid-1700s as an artistic expression of dissent. Depicting herself, the modern artist challenged the absolute authority of the elites by appropriating the privilege of seeing her image. During the 20th century, self-portraiture matured into a space of representation for the fragmented selves, conflicted personalities, and traumatized subjectivities of (post) modernity (Mirzoeff 2016). Self-portraiture is therefore inherently entrenched with duplicity. If it allows the artist to make visible an advantageous image of herself, self-portraiture can also serve as a political paradigm for public confrontation, activism, and identity making (Bryan-Wilson et al. 2016). Acknowledging and embracing this duplicity, we asked the speakers of the confer- ence to use self-portraiture as their framework. Dealing with a city, this framework is inevitably associated with discourses on landscape and urban spectacularization.

Visual culture remains central to the contemporary urban experience. Built environments have been described to mirror social relationships (Lefebvre 1974). The visual quality of a setting, its imageability (Lynch 1960), determines the ability of a city to trigger a sense of identity (Urry, Larsen 2011). Aware of the social and economic implications of this fact, control institutions capitalize on the semiotics of space (Gottdiener 1985). They foster the construction of what Sharon Zukin (1991) forcefully calls the "landscapes of power". The iconization of cities occurs through the global diffusion of a privileged image. One that reduces the complexity of the urban realm to one visual symbol (Ethington, Schwarz 2006). Iconization processes do not guarantee cities a win, but they do grant them a chance to race in the global competition for the attraction of capital. The emphasis on the visual does not only permeate the transnational arena. The spectacularization of everyday life infiltrates both the public and the private realms of contemporary urban existences (Bryman 2004; Friedberg 1994; Ritzer 1999).

And, the show goes on everywhere. It prompts, for instance, the proliferation of themed residential clusters for the new middle classes in China (Bosker 2013; Fraser 2000; Wu 2010). The spectacle is also associated with the management of poverty in the Global South. Slum tours emblematize the romanticization of poverty and serve the Western construction of nostalgic imaginaries (as in Boym 2001) of the not -yet- developed other (Dovey, Ross 2012; Jones, Sanyal 2015, and Banerjee forthcoming). Aestheticizing codes are used as normative frames to legitimize, or not, informal settlements (Roy, Ong 2011; Ghertner 2015).

Analyzing the representational regimes of cities is momentous in illuminating the complexities of contemporary urban dynamics. Better, this analysis can help to outline and dismantle the structuring principles 
of urban injustices. Shanghai is the ideal city to look at for this scope.

China's dominant role in the global economy is acknowledged. During the last three decades, Chinese cities have transformed at a stunning pace transitioning from a centrally planned economy to a market-driven system (Campanella 2008; Ren 2013; Wu, Gaubatz 2013). Within the context of the post-Mao reforms, Den Xiaoping designated Shanghai as the symbol of the Chinese re-birth in 1992 (Chen 2009). This declaration mirrored the intention to give urbanization new meanings that would boost consumption and capital accumulation. The reconfiguration of Shanghai did not come without social polarization, marginalization of vulnerable populations, and environmental issues. What aspects of Shanghai do the local actors of Shanghai emphasize in order to compete for the attraction of capital? How have these narratives shifted over time? And, what groups engage in the production of counter-narratives that contest and resist the dominant rhetoric? The authors of the papers presented in this issue seek answers to these questions.

The interdisciplinary nature of Shanghai, a (Self) Portrait reflects on the diversity of the works presented in this special issue. We organized the papers in three groups. The first three papers focus on issues of architecture and urban planning. The second group looks at narratives of Shanghai presented in movies, literature, and the press. We conclude this special issue with one paper from the professional realm that contains policy recommendations for Shanghai future development.

Zhong Xiaohua and Chen Xiangming open the first group of papers. They analyse the evolution of Shanghai's historical and cultural heritage preservation approaches. Looking at the projects in Xintiandi, Tianzifang, and Bugaoili they emphasize the changing nature of the heritage industry and find a new trend in the managements of Shanghai's past. One that seems more sensible to instances of participation and inclusion.

Following, Ettore Santi examines the condition of uncertainty driving the everyday professional practice of architects in Shanghai. He argues that the identity of Shanghai's built environment is the product a heterogeneous ensemble of cultural constructions and political relations among diverse actors, rather than an a priori condition.

Maria Chiara Tosi, Margherita Turvani, and Stefano Munarin conclude the first group of papers with a design oriented piece. They present the outcome of a joined design studio that engaged students and faculty from both IUAV and the Tongji University. Assuming the correlation between the wellbeing of citizens and the quality of public spaces, they analyse the urban fabric of the Cao Yang New Village with a Nolli-map approach. A set of minimal interventions in the built environment, they argue, will enhance the walkability, connectivity, and porosity of the area.

The second group of papers is inaugurated by Marco Ceresa, who traces the representation of Shanghai in Western movies from the 1930s to date. Ceresa argues that the Asian City, and Shanghai in particular, is usually represented to emblematize a dystopian dreamylike vision of modernity. This Asianization of the future culminates in the movie $\mathrm{Her}$, in which Los Angeles and Shanghai merge together emblematizing the a-territoriality of the neo-liberal cosmopolis.

Paolo Magagnin follows with his piece on Xiao Bai's novel Zujie. Published in 2011, the book narrates of a never existed 1930s Shanghai by combining fiction and real facts. Magagnin critically analyses the novel's literary genres, models, and narrative techniques. He argues that both the Chinese and Western literary traditions innovatively coexist in Xiao Bai's work.

Laura De Giorgi takes us back to present with her paper about how the Chinese press industry portrays the presence of foreign migrants in Shanghai, and expats communities in particular. Reviewing newspapers in both English and Chinese, De Giorgi unveils the ambiguity in the politics of representation of foreigners. Ultimately, she argues, the Chinese press depicts the outcomes as willing to acknowledge the high status of Chinese culture. De Giorgi calls this Chinese attitude towards the expats Sinicized Cosmopolitanism.

Serge Salat concludes this special issue with a policy oriented paper in which he lists the measures that would increase the coordination between spatial planning and investments in transit infrastructure.

The contributions of this special issue offer a multi-faceted view on the ways in which the image of Shanghai is produced and propagated at domestic and transnational levels. As any other collection, this selection of papers is partial. Rather than offering an exhaustive depiction of the representational regimes of Shanghai, this work suggests that an inter-disciplinary approach is instrumental in revealing how the institutional, social, and cultural actors produce diverse narratives. Looking at how these narratives coexist -and at times compete- reveals the paradoxes and frictions associated with contemporary urban making processes.

\section{References}

Banerjee, T. The images of development. Forthcoming 2018.

Basso, M. 2016. The national urban agenda in China: priorities, actors, and tools for cities in search of "stabilization", in European Urban Research Association Conference, 16-18 June 2012, Turin, Italy. 
Bosker, B. 2013. Original copies: architectural mimicry in contemporary China. Honolulu: University of Hawa'i Press.

Boym, S. 2001. The future of Nostalgia. New York: Basic Books.

Bryan-Wilson, J.; Gonzales, J.; Willsdon, D. 2016. Editor's introduction: themed issue on visual activism, Journal of Visual Culture 15(1): 5-23. https://doi.org/10.1177/1470412915619384

Bryman, A. 2004. The disneyization of society. London: Sage.

Campanella, T. J. 2008. The concrete dragon. China's urban revolution and what it means for the world. New York: Princeton Architectural Press.

Chen, X. 2009. Introduction. A globalizing city on the rise. Shanghai's transformation in comparative perspectives, in X. Chen (Ed.). Shanghai rising. State power and local transformations in a global megacity. Minneapolis, London: University of Minnesota Press, pp. XV-XXXV.

Dovey, K.; Ross, K. 2012. Informal urbanism and the taste for slums, Tourism Geographies 14(2): 275-293. https://doi.org/10.1080/14616688.2011.613944

Ethington, P.; Schwartz, V. 2006. Introduction: an atlas of the urban icons project. Urban History, 5-19.

Foucault, M. [1966] 2012. The order of things. London: Routledge.

Fraser, D. 2000. Inventing oasis, luxury housing advertisements and reconfiguring domestic space in Shanghai, in D. Davis (Ed.). The consumer revolution in Urban China. Berkeley: University of California Press, 25-53.

Friedberg, A. 1994. Window shopping: cinema and the postmodern. Berkeley: Univ. of California Press.

Ghertner, D. A. 2015. Rule by Aesthetics: world-class city making in Delhi. Oxford: Oxford university press. https://doi.org/10.1093/acprof:oso/9780199385560.001.0001

Gottdiener, M. 1985. The social production of urban space. Austin: University of Texas Press.
Jones, G. A.; Sanyal, R. 2015. Spectacle and suffering: the Mumbai slum as a worlded space, Geoforum 65(1): 431-439. https://doi.org/10.1016/j.geoforum.2015.02.008

Lefebvre, H. 1974. The production of space $=$ La production de l'espace. Oxford, UK: Blackwell.

Lynch, K. 1960. The image of the city. MIT Press.

Mirzoeff, N. 2016. How to see the world: an introduction to images, from self-portraits to selfies, maps to movies, and more. New York: Basic Books.

Piazzoni, M.-F. The real fake: authenticity and themed environments. The case of Thames Town, Songjiang New Town, Shanghai. Fordham University Press. Forthcoming 2017.

Pointon, M. 2013. Portrayal and the search of identity. London: Reaktion.

Ren, X. 2013. Urban China. Cambridge, UK; Malden, MA: Polity Press.

Ritzer, G. 1999. Enchanting a disenchanted world: revolutionizing the means of consumption. Thousand Oaks: Pine Forge Press.

Roy, A.; Ong, A. 2011. Worlding cities: asian experiments and the art of being global. Chichester, West Sussex: WileyBlackwell. https://doi.org/10.1002/9781444346800

Urry, J.; Larsen, J. 2011. The Tourist Gaze, 3rd edition. London: Sage.

Wu, F. L. 2010. Gated and packaged suburbia: packaging and branding chinese suburban residential development, Cities 27(5): 385-396. https://doi.org/10.1016/j.cities.2010.06.003

Wu, W.; Gaubatz, P. 2013. The Chinese city. London; New York: Routledge.

Zukin, S. 1991. Landscapes of power: from Detroit to Disney World. Berkeley: University of California Press. 